\title{
Fiscal Restraint, Total Demand and Monetary Policy
}

OTAL demand for goods and services has continued to rise sharply, placing excessive claims on our nation's resources. Total spending increased 9 per cent in the year ending in the second quarter, and pulled up prices by 4 per cent. From mid-1965 to mid-1967, spending rose at a 7.5 per cent average annual rate and prices advanced at a 2.6 per cent rate. Excessive total demand in recent years has been fostered by a combination of very stimulative fiscal and monetary actions.

On June 28, the "Reventue and Expenditure Control Act of 1968" was signed into law. This legislation was designed to alter the influence of the Federal budget so as to restrain private and Government spending and thereby dampen inflationary pressures. Included in the Act are provisions which increase tax rates on individual and corporate income, extend excise tax rates on automobiles and telephone service at existing rates and moderate the growth of Govermment expenditures. Implementation of the Act is expected to reduce sharply the Federal budget deficit.

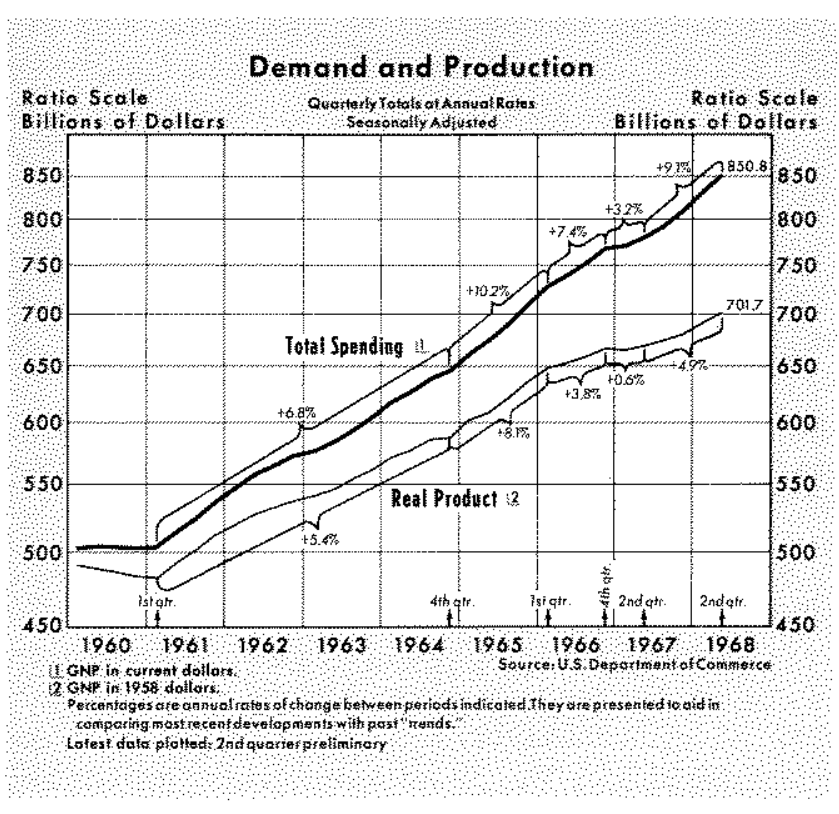

The fiscal program as proposed is intended to moderate the budget stimulus as a factor contributing to the current inflationary situation. This note assesses the economic impact of the Act of 1968 by focusing on the following considerations:

1. Recent trends in the growth of total demand, real product and prices.

2. The outlook for growth of total demand, real product and prices in light of the new fiscal program.

3. The outlook for the U.S. balance of payments.

4. The outlook for financial markets and the implications for monetary action.

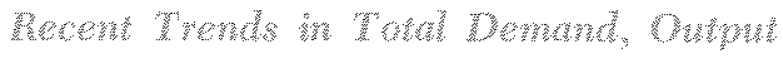 whil prates}

Total spending for goods and services rose 9 per cent from the second quarter of 1967 to the second quarter of 1968 , accelerating from the 7.5 per cent annual rate for the previous two years. From 1957 to 1965 , total spending had increased at a 6 per cent annual rate.

Total output of the economy expanded 5 per cent in the year ending second quarter, an unsustainable rate of growth. Expansion of real product is constrained by the growth of productive potential, which is estimated to be increasing about 4 per cent per year.

As a consequence of the rapid increase in the demand for goods and services relative to supply, the rate of price increase has accelerated. The general level of prices advanced 4 per cent in the last year, compared with a 3 per cent average rate over the previous two years and a 1.6 per cent rate from 1957 to 1965 .

The intensified inflationary pressures have been encouraged by highly expansionary monetary and fiscal actions. The high-employment budget moved from a $\$ 7$ billion annual rate of surplus in the first half of 
1965 to a $\$ 14$ billion deficit in the first half of 1968 . By comparison, this budget averaged a $\$ 9$ billion surplus from 1957 to 1965 . The nation's money stock rose at a 5 per cent annual rate from early 1965 to mid-1968, compared with an annual rate of 2.2 per cent from 1957 to 1965 .

\section{The Then Wrogm}

The primary purpose of the Act of 1968 is to reduce inflationary pressures by moderating the growth of total demand. Taking into account the fiscal program and recent estimates of expenditures, the highemployment budget is expected to move to a $\$ 12$ billion rate of surplus in the first half of 1969 from a rate of deficit of $\$ 14$ billion a year earlier. ${ }^{ \pm}$

The major features of the fiscal package are a reduction in spending for some items from the level proposed in the Government's budget for the year ending June 30,1968 , and a 10 per cent surcharge on corporate and individual income taxes. The surcharge on corporate income tax liability is retroactive to January 1. For individuals the surcharge is retroactive to April 1, which will mean a 7.5 per cent increase in taxes on personal income earned in 1968.

The expenditure cuts included in the program apply to the level of spending in the Government's official budget which was proposed for the fiscal year beginning July 1 . In the January budget message, the President proposed spending and net lending of

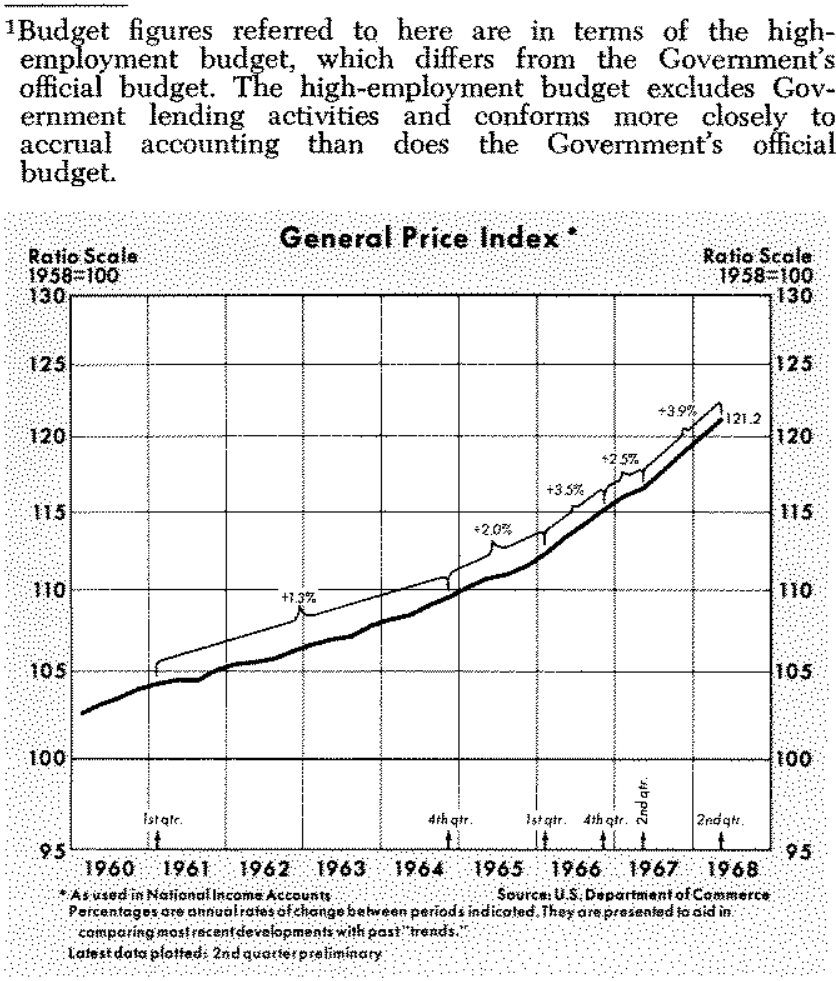

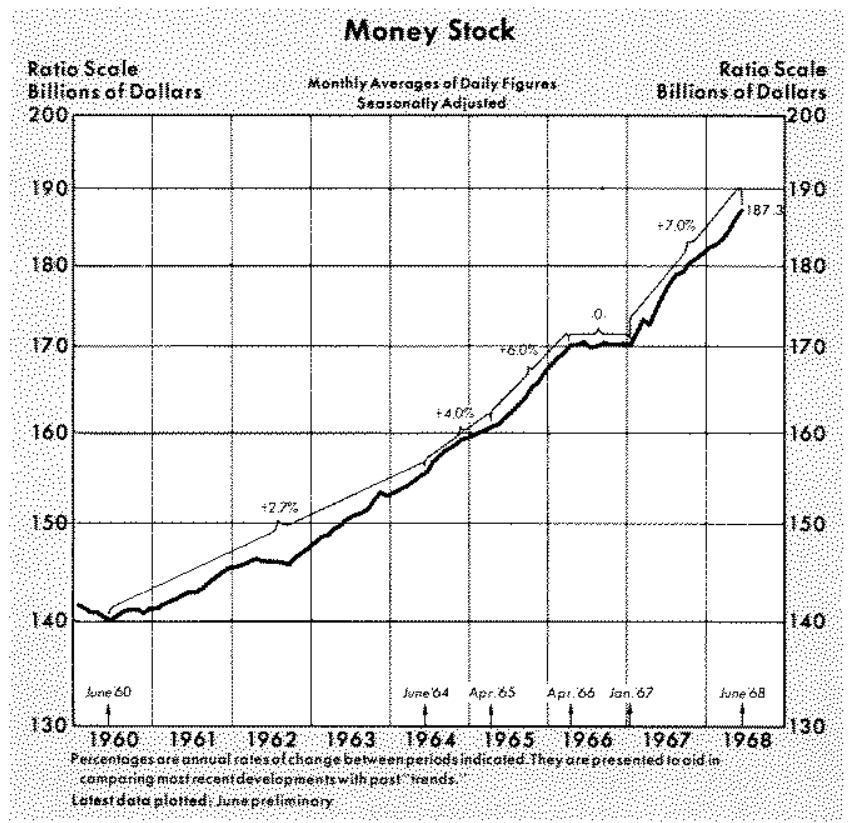

$\$ 186.1$ billion in fiscal 1969 . The fiscal program calls for limiting the level to $\$ 180.1$ billion, an increase of $\$ 1.2$ billion from fiscal 1968. Spending in excess of this amount is allowable, however, if needed for special support of Vietnam operations, interest on the national debt, or veterans' and social security benefits. Expenditure estimates for Vietnam in fiscal 1969 have already been revised upward by $\$ 2.6$ billion from the level proposed in the budget. Interest on the national debt is now expected to be almost $\$ 1$ billion higher than previously estimated.

Taking into account revised expenditure estimates and assuming other expenditures are controlled according to the program, Federal spending on a highemployment budget basis is now expected to rise 2.4 per cent from the first half of 1968 to the first half of 1969. By comparison, high-employment budget expenditures rose at a 15 per cent annual rate from mid-1965 to 1968, and at a 6 per cent rate from 1957 to 1965 .

The tax provisions of the program, plus an increase in social security taxes effective January 1, 1969, would provide an estimated $\$ 13$ billion in additional revenue in the year ending June 30,1969 . This estimate includes $\$ 7$ billion from individual income taxes, $\$ 3$ billion from the corporate surcharge, and $\$ 3$ billion in increased social security taxes.

The shift from deficit to surplus in the budget reflects, in addition to the effects of changed tax rates, normal growth of revenues in an expanding economy. If the tax surcharge is allowed to expire on June 30 , 1969 , it is estimated that the high-employment budget surplus will drop sharply to near balance in the third 
quarter of 1969 . The reliability of these projections depends on how far the programs which are exempt from the spending restrictions deviate from the levels proposed in the January budget, and the extent to which other programs are effectively limited by expenditure controls.

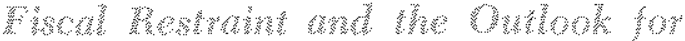

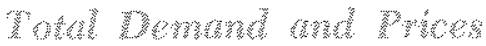

The Revenue and Expenditure Control Act is designed to reduce the stimulative infuence which fiscal actions have exercised on the economy since 1965. The amount of resources which has been required for Vietnam operations has been greatly underestimated since 1965 and, as a result, expenditures for defense have risen faster than budgeted amounts. The sharp expansion of defense spending was under. taken as the Government was accelerating expenditures for domestic programs. Total outlays far outpaced revenue, resulting in substantial budget deficits. Federal Reserve action to reduce the impact of heavy Government borrowing on financial markets resulted in rapid monetary expansion. The combination of these fiscal and monetary developments stimulated total demand, and the resulting pressure on a fully-employed economy has been a major factor contributing to price inflation and high interest rates.

Estimating the impact of the new fiscal program is an inexact, but very important matter, and an assessment of this impact is facilitated by examining key segments of total demand in some detail.

Personal Consumption. The thrust of the tax portion of the fiscal program is aimed at individuals, who will have to pay almost $\$ 7$ billion in extra taxes

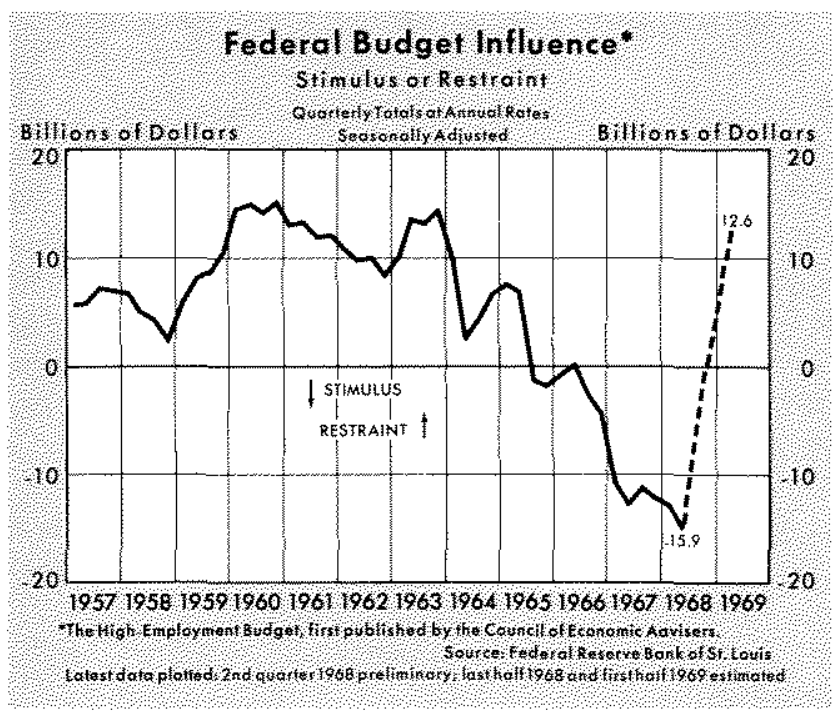

in the year ending June 30,1969 . The surcharge is expected to reduce the growth of consumer spending by moderating gains in take home pay. The manner in which consumers respond to higher taxes will determine, in large measure, the impact of this part of the fiscal program.

The extent to which individuals choose to pay their increased tax liabilities from past saving, or by reducing current saving, will tend to moderate the restrictive effects of the fiscal program. From late 1966 to mid-1968, individuals allocated a larger share of their income to savings. Personal saving averaged 7 per cent of disposable personal income over the period, compared with an average rate of 6 per cent from 1957 to 1966. A reduction in the saving rate of one percentage point over the next year would free almost $\$ 6$ billion for spending, negating a large portion of the restrictive effect of increased taxes.

Individuals base current spending plans to some degree on past experience. The flow of income to which persons have become accustomed is a very important determinant of current and future consumption. The fact that individuals have been accumulating a large amount of savings relative to income suggests that the restraining effect of the added tax may be attenuated. In addition, the ostensibly temporary nature of the surcharge provides consumers with an added incentive to regard the reduced flow of income as a short-run factor, and to use their wealth position to maintain spending.

Business Investment. Expenditures for plant and equipment are based mainly on long range projections, and therefore depend on sales expectations over an extended period. If businesses observe only moderate easing of growth in consumer spending, they will have continued incentive to carry through with investment plans.

The cost and availability of funds are also important in determining the strength of investment spending. Easing of upward pressure on market interest rates might influence businesses to borrow funds for investment projects. Such a development would counter the restrictive effect of the tax hike via reduced cash flow to businesses. Furthermore, the fiscal package introduces the prospect of a tax advantage for investment programs undertaken during the period when increased tax rates are in effect, making the investment tax credit more attractive.

Government Demand. Rapid expansion of Government demand has been a major factor contributing to the sharp increase in total demand experienced since mid-1965. The provisions limiting Federal expendi- 
tures in fiscal 1969 imply a reduction in the growth of Government demand for goods and services. However, the ability of the Government to restrain expansion of its demand for resources in the present fiscal year remains to be proved.

Summary of Outlook for Total Demand. Aggregate demand probably will continue to be strong for some time, reflecting stimulative fiscal and monetary actions in the recent past. There is some doubt whether fiscal actions will restrain economic activity greatly in the immediate future. Many factors suggest that both consumer and business spending may not respond to the program of fiscal restraint to a degree sufficient to reduce the pressure on prices significantly.

In addition to the pull of current total demand, cost factors, reflecting past excessive demands, are also exerting upward pressure on prices. The inflationary situation which has prevailed in the economy since 1965 has induced labor to seek wage settlements which will compensate for purchasing power lost to past price increases. The prolonged period of inflation has probably also caused some pressure for compensation for expected future inflation. The fiscal package can do little immediately to dampen this pressure. The tax hike itself might stimulate demands for even larger settlements.

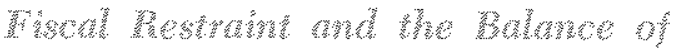 \\ Paymen}

The impact of the fiscal program on total demand and prices has important implications for the U.S. balance of payments. The United States economy has experienced a sharp decline in its foreign trade surplus, reflecting the adverse effects of a rapid growth of imports. Acceleration of domestic income has increased the demand for foreign goods. If the trade balance is to be restored to the strong surplus position of previous years, the relative price position of American products must be improved.

Since the rate of price increase cannot be expected to moderate to a significant degree soon, little improvement in the balance of payments can be expected as the result of increased exports. Continued rapid expansion of aggregate demand would also tend to maintain imports at a high level relative to exports. With little likelihood of rapid and significant improvement on current account, capital flows become the prime vehicle for improvement. In the first half of 1968, high interest rates attracted a large amount of foreign capital into the United States. Interest rate declines in the second half of 1968 would reduce the inflow of such capital.

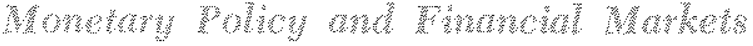

The fiscal program, if strictly followed, is expected to reduce Government borrowing needs in fiscal 1969 by about $\$ 20$ billion from the level of fiscal 1968 . This suggests that a great deal of the upward pressure on interest rates will be removed over the course of the fiscal year.

The response of monetary developments to such possible easing of credit conditions deserves attention. Federal borrowing needs remain relatively large in the second half of calendar 1968. The pressure of this demand on financial markets, in addition to expected corporate borrowing to meet first half tax liabilities, suggests little immediate moderation in the demand for lendable funds. Monetary expansion to provide downward pressure on interest rates could stimulate spending and reinforce upward pressure on prices. Monetary expansion at or above recent rapid rates would then work to negate the restrictive influence of the fiscal program.

The response of corporations and individuals to the tax hike will depend in part on conditions in financial markets. Other things unchanged, high interest rates tend to reduce the amount of funds demanded by business for investment, and tend to increase the attractiveness of saving relative to spending for individuals. Falling interest rates tend to have opposite effects. Within a framework of fiscal actions aimed at reducing the growth of demand for goods and services, and consequently dampening inflationary pressure, monetary expansion to ease pressure on interest rates might encourage both consumer and business spending and discourage private saving.

\section{Cowalustors}

Fiscal authorities have adopted a program of Federal budget restraint in an effort to combat excessive total demand. It is hoped that this action will moderate inflationary pressures while only slightly affecting output and employment. However, an inflationary psychology has become entrenched in the economy, as evidenced by large wage settlements and the rising costs of credit. If the Administration and the Congress have finally assigned high priority to the task of reducing inflationary pressures, monetary actions to complement the fiscal program are needed. The possibility that the restraining effects of the surcharge may be attenuated, and also that expenditure controls may not be fully implemented, reinforces the desirability of avoiding monetary actions that might counter the restrictive effects of the fiscal program. 